خاصيت آنتى باكتر يال داربست هاى متخلخل براى درمان ضايعه استخوانى

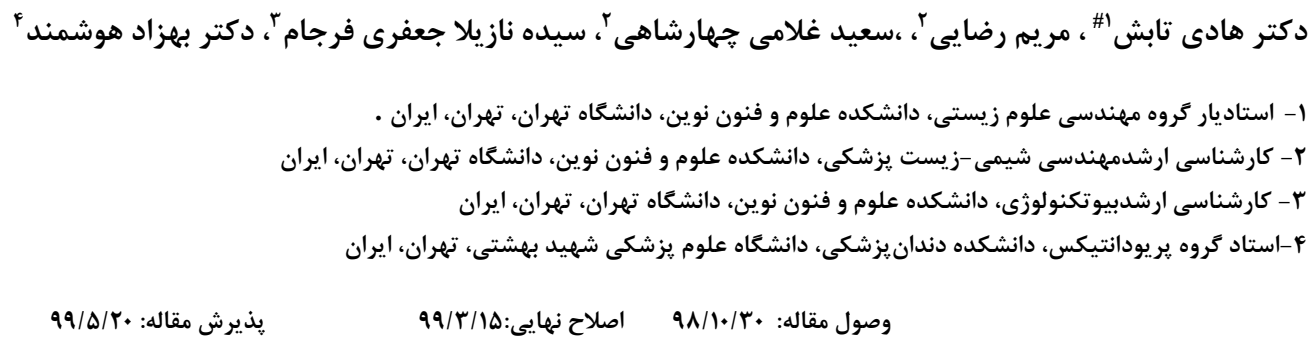

\title{
Development of an antibacterial porous scaffold for bone defect treatment
}

\author{
Hadi Tabesh ${ }^{1}$, Maryam rezaie ${ }^{2}$,Saeed gholami², Nazila Jafari Farjam ${ }^{3}$, Behzad Houshmand ${ }^{4}$
}

1.Assistant Professor, Department of Life Science Engineering, Faculty of New Science and Technologies, University of Tehran, Tehran, Iran. 2.M.Sc. of Chemical/Biomedical Eng., Department of Life Science Engineering, Faculty of New Science and Technologies, University of Tehran, Tehran, Iran.

3.M.Sc of Biotechnology., Department of Life Science Engineering, Faculty of New Science and Technologies, University of Tehran, Tehran, Iran.

4. Professor, Periodontics Dept, Dental School, Shahid Beheshti University of Medical Sciences, Tehran, Iran.

\section{Received: Dec 2020 ; Accepted: JUNE 2021}

\section{Abstract}

Background \& Aim: The use of bone scaffolds is one of the new and efficient techniques for repairing bone defects that provide a suitable platform for cell proliferation and growth to repair the target tissue. One of the most important causes of failure of transplants and surgical procedures is the invasion of bacteria at the site of the complication and the development of severe infection. The purpose of this study, which was carried out at the Faculty of New Sciences and Technologies, University of Tehran at 2017-2019, Antibacterial Properties of Porous Scaffolds Made of Gelatin, Calcium Phosphate Zeolite with Loading of Clindamycin.

Material and methods: In this study, freeze-drying was made from a combination of gelatin, calcium phosphate, and natural zeolite of bone tissue scaffolds and then the drug was loaded with different amounts of clindamycin. The surface of the scaffold was examined by scanning electron microscopy and antibacterial test and drug release test were performed on the scaffold.

Results: The results showed that the aforementioned composite scaffold did not induce growth inhibition in the antibacterial test, However, after loading the drug on the scaffold with a concentration of $0.01 \mathrm{drug}$, the growth zone was 2 and $4 \mathrm{~mm}$ in diameter for Escherichia coli and Staphylococcus aureus, respectively.

Conclusions: Addition of the antibacterial agent clindamycin to the bone scaffold made a suitable substrate for drug delivery to bone tissue at the site of removal has been removed to prevent the growth of infection at the scaffold implant during the first period of repair.

Key words: Bone Tissue, Scaffold, Antibacterial Drug, clindamycin.

\# Corresponding Author: hadi.tabesh@ut.ac.ir

J Res Dent Sci. 2021;18(1): 32-40. 
خلاصه:

سابقه و هدف: استفاده از داربستهاى استخوانى يكى از تكنيكهاى جديد و كارآمد جهت ترميم مشكلات استخوانى است كه بسـترى مناسـب

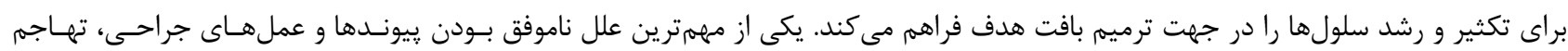

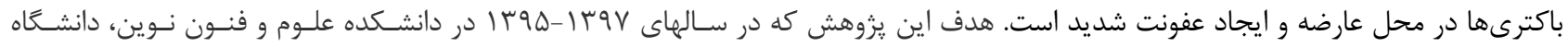

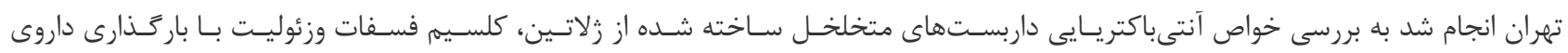
كليندامايسين پرداخته است. مواد و روش ها: در اين يزوهش به روش خشكايش انجمادى از تركيب زلاتين ، كلسيم فسفات و زئوليت طبيعى داربست بافت اسـتخوان توليـد

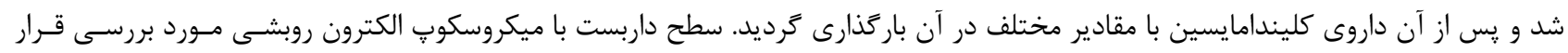

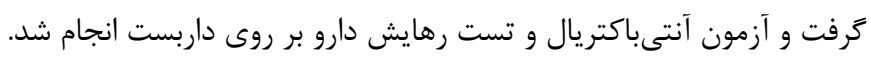

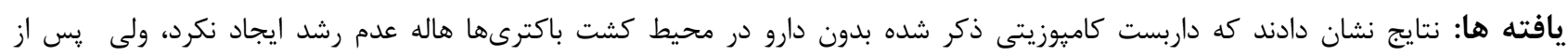

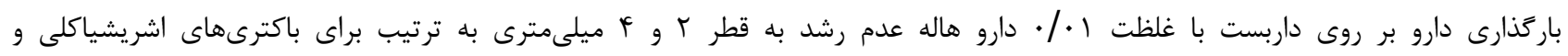
استافيلوكوكوس اورئوس شد. نتيجه كَيرى: افزودن عامل ضد باكتريايى كليندامايسين به داربست استخوانى ساخته شده بستر مناسبى براى دارورسانى به بافت استخوان در محل بافت حذف شده است تا از رشد عفونت در محل كاشت داربست در دوره اول ترميمم جلوكيرى كند. كليد وازهها: بافت استخوان، متخلخل، آنتىباكتريال، كليندامايسين.

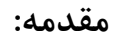

احاطه شد، درمان با واكنش التهابى مواجه مىشود كه به عدم ترميم مناسب استخوان منتهى مى مشكلات زيادى براى بدن مىشود. عفونت مىتواند بافتها را از بين ببرد(r)؛ همجنين احتمال گسترش عفونت در بدن و مبتلا شدن ديخر قسمتهاى بدن به آن مىتواند بسيار خطرناى باشد. يكى از شايعترين ميكروب مولد عفونت استخوان باكترى

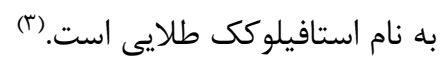
يكى ازمرسومترين راه درمان استفاده از داروى آنتىبيوتيك كه از دو راه طبيعى و مصنوعى به دست مى آيند. آنتى بيوتيكها در سطوح متفاوتى در درمان عفونتها ايفاى نقش مى كنند

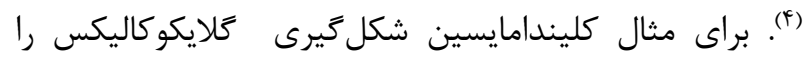
كاهش مى دهد و به رشد فاگوسيتها سرعت مىدهد و عفونت را سركوب مى كند(\&) كليندامايسين در مقابل اركانيسمهايى Plasmodium, , Toxoplasma Babesia, and نظير Pneumocystis spp. مىدهد. استفاده موثر از آنتى بيوتيكها در درمان استئومليت نياز به شناخت مشخصههاى ياتو فيزيولوزيك اين بيمارى دارد. Psedomonas و مهمترين : Staphylococus

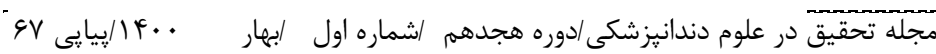

در حال حاضـر داربسـتهاى اسـتخوانى سـاخته شـده از مــواد معدنى و طبيعى، تا حد زيادى جـايخزين زيونـدهاى اسـتخوانى در درمان آسيبهاى استخوانى شدهاند. مـواد انتخــاب شـده در داربستهاى اسـتخوانى بـر اسـاس خــواص مكـانيكى - زيسـتى انتخاب شدهاند. از مهمرترين ويزگى داربستهاى سـاخته شـده مىتوان به زيست فعالى و زيست تخريبيذير بودن آنها اشـاره كرد. (1.r) امروزه يكى از اصلىترين جالشها در زمينه كاشت داربست و ايميلنت در بدن، عفونت ايجاد شده در محل كاشت است كه منجر به خطرات و عوارض جانبى زيادى مى عفونت ناشى از باكترىها در ترميم بافت استخوان يك عارضه نكران كننده است؛ زيراكه خطر تخريب استخوان را بالا مىبرد(1) قرارگرفتن داربست به عنوان جسم خارجى در استخوان، رقابتى بين ياتوزنهاى عفونتزا و دفاع سلولى بدن به راه مىاندازد. اخر باكترىها در اين رقابت برنده شوند، يك لايه بيوفيلم بر روى داربست تشكيل مىدهند كه آنها را از آنتى بيوتيك محافظت مى كند، بنابراين به راحتى به رشد خود ادامه مىدهند. همين كه زرافت استخوانى به واسطه ميكروبها 
متوقف مىكند(·)؛ كه در اين يُوهش به عنوان يك آنتى بيوتيك موثر بر روى داربست ساخته شده باركذارى شده است.

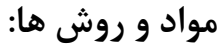

مواد استفاده شده به همراه فرمول شيميايى و شركت سازنده در ساخت اين داربست، به شرح جدول زير است.

\begin{tabular}{|c|c|c|}
\hline شركت سازنده & فرمول شيميايى & ماده شيميايى \\
\hline $\begin{array}{c}\text { ( Exir } \\
\text { AUSTRIA) }\end{array}$ & $\mathrm{Ca}_{3}\left(\mathrm{PO}_{4}\right)_{2}$ & يودر B-TCP \\
\hline $\begin{array}{c}\text { Merck } \\
\text { (GERMNY) }\end{array}$ & $\mathrm{C}_{6} \mathrm{H}_{12} \mathrm{O}_{6}$ & زلاتين \\
\hline $\begin{array}{c}\text { Merck } \\
\text { (GERMNY) }\end{array}$ & $\mathrm{SiO}_{2}$ & خلو خلوص آلدهايد با \\
\hline $\begin{array}{l}\text { UNIVERSITY } \\
\text { OF TEHRAN }\end{array}$ & $\mathrm{H}_{2} \mathrm{O}$ & آب دى يونيزه \\
\hline ماده معدنى & $\begin{array}{c}(\mathrm{NaKCa})_{2-} \\
3\left[\mathrm{Al}_{3}(\mathrm{AlSi})_{2}\right. \\
\left.\mathrm{Si}_{3} \mathrm{O}_{36}\right]_{12} \mathrm{H}_{2} \mathrm{O}\end{array}$ & كلينيبيتولوليت \\
\hline $\begin{array}{c}\text { Merck } \\
\text { (GERMNY) }\end{array}$ & $\mathrm{C}_{18} \mathrm{H}_{33} \mathrm{ClN}_{2} \mathrm{O}_{5} \mathrm{~S}$ & كلينداريسين \\
\hline
\end{tabular}

\section{ساخت داربست}

ابتدا ميزان 99. • گرم زلاتين در • اسى سى آب ديونيزه دوبار تقطير حل كريده و به مدت r ساعت بر روى استيرر با دماى

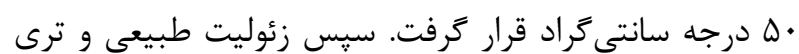
كلسيم فسفات براى انحلال بهتر هركدام در بشر هاى جداكانه به ميزان ه/ • ترم درهاسى سى آب ديونيزه در دستخاه

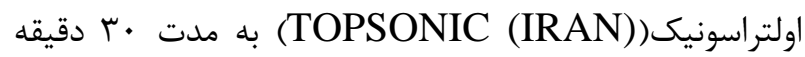
حل گرديد . سيس مواد به ترتيب با يكديكر اختلاط يافتند و كلوتار آلدهيد به ميزان ه. • درصد حجمى-حجمى به آن افزوده شد و در نهايت داروى كليندامايسين به آرامى و با توجه به مقادير جدول شماره Y به آن افزوده شد كه در نتيجه داربست

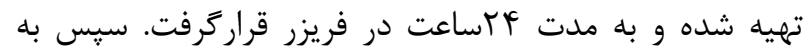
Operon- FDB-5503 مدت Fر ساعت در فريزدراير( (model (KOREA)

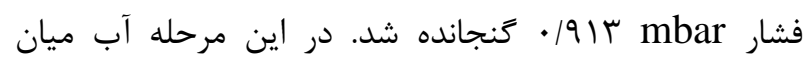
صفحات داربست مستقيما تبخير شده و باعث تشكيل حفرات و و ايجاد تخلخل در داربست مىشود. داربست پِ از خروج از فريز
مسئول اين عفونت در بدن انسان است. در •و درصد مواقع عفونت استئوميليت به همراه ايميلنت كذارىها در محل با ياتوزن Staphylococus حادث مىشود (ه.ه.). از طرفى اين روش درمان هم به علت خونرسانى ضعيف به بافت استخوان با غلظت هاى زياد دارو خوراكى و يا تزريقى انجام و همراه با بان بان جالشها و مشكلات زيادى است. با سيستم داروسانى و قرصهاى سنتى ميزان دارو در خون

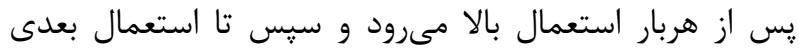
دارو، اين ميزان افت مى كند و در هر بار استفاده دورهاى دارو، غلظت آن كاهى كمتر از حد موثره و پِ از استعمال به بيش از حد موثره كه سمى است، مىرسد. در سامانه هاى دارورسانى

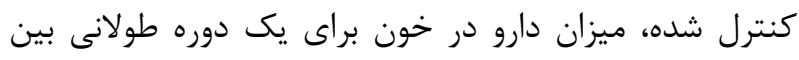

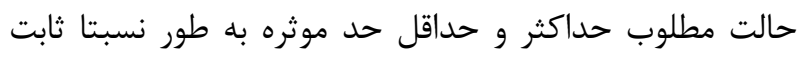

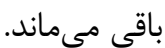
در انجام اين يزوهش، م-TCP مورد استفاده قرار ترفته است كه به دليل شباهت با ساختار استخوان طبيعى در ترميم استخوان بسيار يركاربرد بوده ولى در مقابل، بسيار تخريب يذير است و بخاطر شكنندگى و تردى، خواص مكانيكى ضعيفى دارد

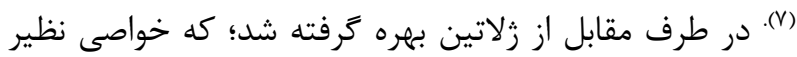

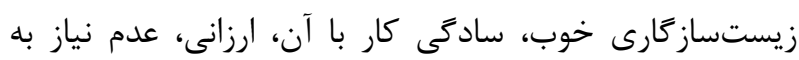

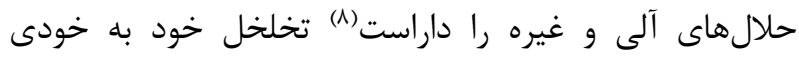
زلاتين، سبب به وجود آمدن خلل و فرج مى گردد و از طرف ديخر در ساخت اين داربست بيش از پيش روش خشكايش انجمادى مورد استفاده قرار مى گيرد كه در نتيجه يزوهش مورد نظر ما را نيز به همين سمت سوق داده است. زئوليت طبيعى نيز ديخر مادى مورد استفاده در اين فرآيند است به خاطر ويزَّى سطحى مناسب، داشتن خلل فرج و تاثير گذارى در سامانه هاى رهايش دارو و همينطور خواص استحكامى مناسبتر نسبت به HA مو ، مورد تحليل قرار مى كيرد (9).

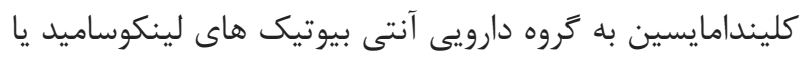

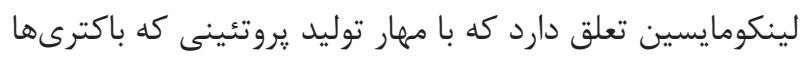
براى يخش عفونت در بدن نياز دارند، فعاليت باكترىها راسئ 
مقايسه شد و زمانيكه كه كدورت هر دو محلول يكسان بودند، بوسيله سواٍ استريل از محلول باكترى برداشته و روى یترى ديش حاوى محيط كشت آكار به صورت جمنى كشت داده شد. داربستهاى تهيه شده از زئوليت طبيعى و ترى كلسيم فسفات و زلاتين به همراه داروى كليندامايسين در غلظتهاى مختلف و بدون دارو به صورت مساوى برش داده و يس از شست و شو در آب مقطر به مدت • r دقيقه در ه سانتى مترى نور قرار داده شدند، سيس داربستها با فاصله از هم روى محيط كشت حاوى باكترى در ץ تكرار قرار داده شدند. پترى ديشها به مدت دو ساعت درون يخجال قرار داده شدند و سيس به مدت F T ساعت در دماى TV درجه سانتى گراد نغهدارى شدند. كليندامايسين از ديسك به محيط اطراف منتشر شده و مانع از رشد باكترىهاى مورد استفاده مى شود. با اندازه گيرى قطر هاله عدم رشد به سادگى مى توان حساسيت باكترى را نسبت به داربستهاى مختلف كه حاوى داروى كليندامايسين هستند را تعيين نمود. هاله عدم رشد باكترى در اطراف داربستها روى محيط كشت باكترى نشان دهنده خاصيت آنتىباكتريال نمونهها است. قابل ذكر است كه مقدار حداقل غلظت مهار كليندامايسين با توجه به يزوهشها ثاع ميلى

$$
\text { ليتر كزارش شده است (11) }
$$

ساخت محلول استاندارد نمودار كاليبراسيون براى تهيه محلول استاندارد براى رسم نمودار كاليبراسيون ابتدا ا گرم از داروى كليندامايسين را در · إيلىليتر آب ديونيزه حل كرده و سيس با استفاده از روابط استوكيومترى آن را تا رقت أmg/ml رقيق كرده و و يس از آن با توجه به نتايج

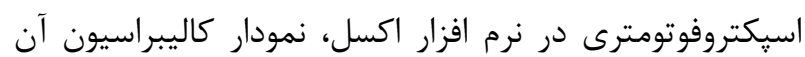

$$
\text { راناليز رهايش مىشود. }
$$

براى انجام آناليز رهايش دارو، محلول PBS به دليل شباهت

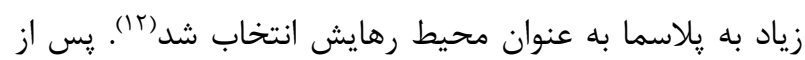
ساخت داربستها، دايرههايى با قطر ا سانتىمتر كه تقريبا وزن يكسانى داشتهاند را از داربستها برش داده و در محلول PBS بصورت معلق قرار كرفتند. جهت توزيع يكنواخت دارو در
دراير وسه بار شست و شو دادهد و به وسيله آون خشك كَرديد. در جدول انواع داربستهاى ساخته شده در اين يروهش

\begin{tabular}{|c|c|c|c|}
\hline GTZ-C & $\begin{array}{l}\text { GTZ- } \\
\text { B }\end{array}$ & GTZ-A & نام اختصارى \\
\hline$\cdot \cdot 1$ & $\cdot .1$ & . & مقدار دارو (g) \\
\hline. $.99 \mathrm{~g}$ & $\cdot .99 \mathrm{~g}$ & $\cdot .99 \mathrm{~g}$ & مقدار گرم زلاتين \\
\hline$\cdot . \Delta \mathrm{g}$ & $\cdot \Delta \mathrm{g}$ & $\cdot \Delta \mathrm{g}$ & مقدار گرم كلسيم \\
\hline$\cdot . \Delta \mathrm{g}$ & $\cdot . \Delta \mathrm{g}$ & $\cdot . \Delta \mathrm{g}$ & مقدار زرم زئوليت \\
\hline
\end{tabular}
آورده شدهاست. جدول - انواع داربستهاى ساخته شده

آناليز ميكروسكوٍ الكترونى روبشى (SEM)

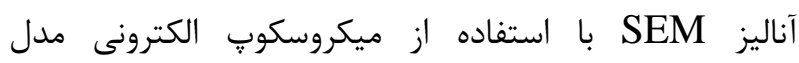
AIS2100 (Scanning Electron Microscope) شركت سازندهى SERON TECHNOLOGIES كشور كرهجنوبى مورد بررسى قراركرفته است. از اين دستگاه جهت

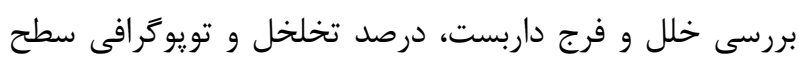
داربست استفاده شده است.

انجام تست آنتىباكتريال به روش ديسك سدي ديفيوزن براى تشخيص فعاليت ضدميكروبى داربست زئوليت طبيعى و ترى كلسيم فسفات و زلاتين به همراه داروى كليندامايسين در

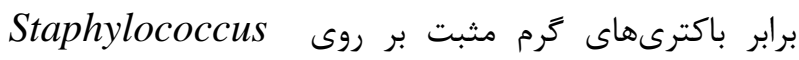
aureus

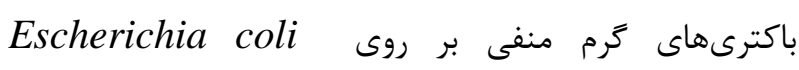

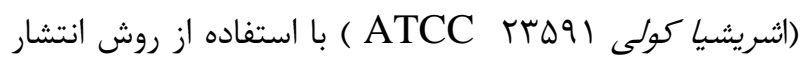
ديسك در آكار بررسى شدند. ابتدا در زير هود بيولوزيك، مقدار يك تا دو تك كلنى از باكترى هاى رشد يافته بر روى محيط

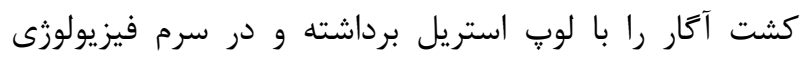

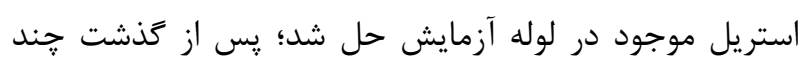

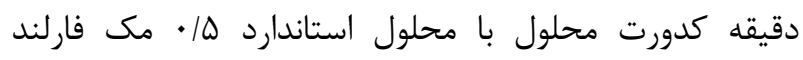


در اطراف داربست رشد كردهاند. در داربست C باكترى در زير داربست نتوانسته است رشد كند و هاله عدم رشد قابل دركى در اطراف داربست مشاهده نمىشود. در داربست B كه ميزان داروى باركذارى شده بيشتر از داربست C است هاله عدم رشد در اطراف

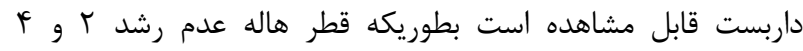
ميلىمترى به ترتيب براى باكترىهاى اشرشياكلى و استافيلوكوكوس

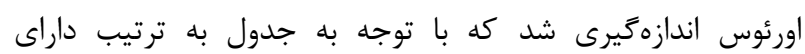
حساست ميانى و بالا بودند. با افزايش غلظت دارو، افزايش خواص آنتى باكتريال قابل مشاهده است.
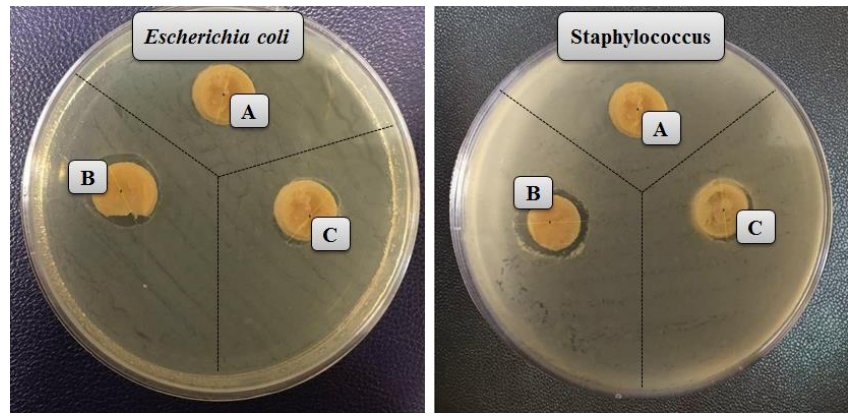

شكل r- تصاوير قطر هاله رشد در حضور دو نوع باكترى

در جدول ب با استفاده از نرم افزار Image J قطر هاله رشد براى هر داربست در حضور هر دو باكترى اندازهخيرى و نشان

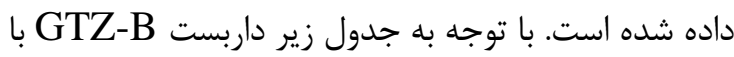
بيشترين غلظت دارو، بيشترين هاله عدم رشد را دارا است.

\begin{tabular}{|c|c|c|c|}
\hline \multicolumn{4}{|c|}{ جدول ؟.اندازهيرى قطر هاله رشد داربستها } \\
\hline 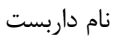 & قطر هاله باكترى & قطر هاله & قطر هاله \\
\hline & الورئوس(mm) استوكوكوس & أشرشياكلى اكى & 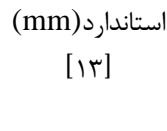 \\
\hline
\end{tabular}

\begin{tabular}{lccc}
\hline G & & & $\mathrm{S}>18$ \\
TZ-A & $\cdot$ & $\cdot$ & \\
\hline GTZ-B & $\uparrow / / \uparrow+\cdot \cdot \vee$ & $r / / \uparrow+\cdot 1$ & $16<\mathrm{I}<17$ \\
& & & \\
\hline GTZ-C & $\mid \uparrow+\cdot / \Lambda \wedge$ & $\cdot / / \uparrow+\Delta \mid$ & $\mathrm{R}<15$ \\
& & & \\
\hline
\end{tabular}

محيط رهايش، نمونهها بر روى شيكر اوربيتال با دور 1 rpm قرار گرفتند. پس از هر بار نمونهبردارى كه V روز هر عاع ساعت يكبار انجام شد، محلول PBS تازه جايخزين محلول قبلى مى شد و توسط دستخاه اسيكتوروفوتومتر ( NanoDrop 2000/2000c Spectrophotometer. V1.0 User (Manual كمك نمودار استاندارد غلظت داروهاى رها شده در محلول محاسبه مىشود.

\section{يافتهها}

$$
\text { آناليز ميكروسكوب الكترونى روبشى }
$$

با توجه به شكل ا، خلل و فرجهاى باز و بههم پييوسته با اندازه متناسب براى رشد و عبور سلولها، كمك شايانى به تمايز سلولى و رگزايى در بافت مى كند. سايز اندازه حفرات با توجه

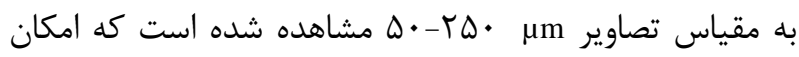
ورود سلول به داخل داربست و همجنين دفع ضايعات سلولى را

$$
\text { فراهم مى كند }
$$

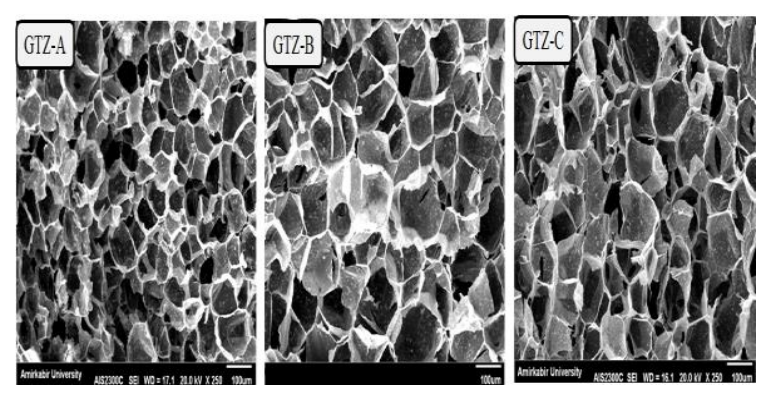

$$
\text { شكل ا- تصوير SEM داربست استخوانى كلسيم }
$$

فسفات/زلاتين /زئوليت و داربست به همر اه داروى كليندامايسين

$$
\text { تست آنتىباكتريال }
$$

نتايج حاصل از بررسى داربستهاى ساخته شده با غلظتهاى

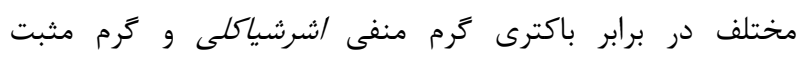
استافيلوكوكوس /ورئوس در شكل ب آمده است. همانطور كه در شكل rامشاهده مى كنيد، داربست A كه دارويى در در آن باركذارى نشده، هاله عدم رشدى تشكيل نشده است؛ و باكترىها 
خوردَى، زيست سازگًارى و فعاليت ضد ميكروبى داربست

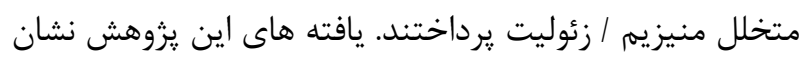

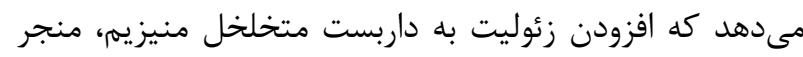
به مقاومت در فشارى بالاتر و مقاومت در برابر خوردىى شده

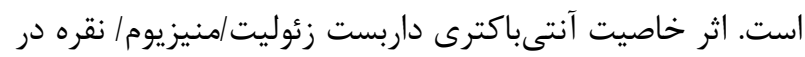

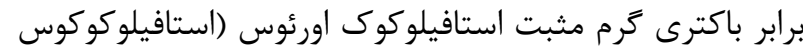
اورئوس) و كرم منفى اشرشيا كلى (E. coli) حاكى از اين است كه تريكب نقره/ئوليت نقش بهسرايى در جلوگيرى رشد باكترىها داشتهاست. در مطالعه ديكرى يس از طراحى و

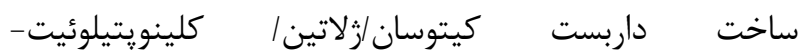
نانوهيدروكسى آياتيت به بررسى تاثير آن بر مهندسى بافت

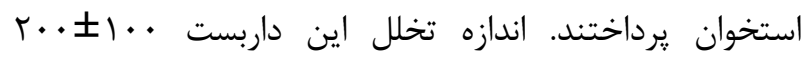
ميكرومتر بوده است و همجنين هيج سميتى بر روى سلولها

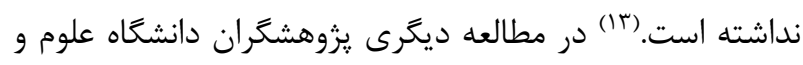
تكنولوزى استامبول تركيه موفق به ساخت داربست كاميوزيتى clinoptilolite/alumina/bovine hydroxyapatite (Cp A12O3 - BHA) composite

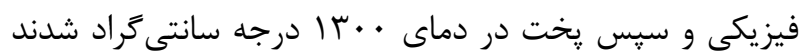

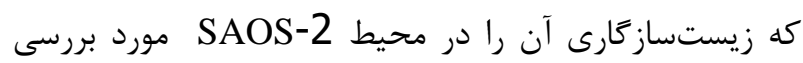

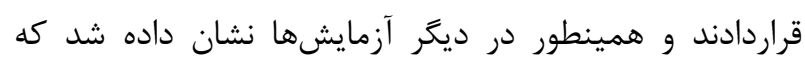

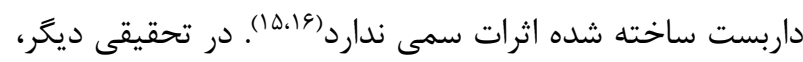

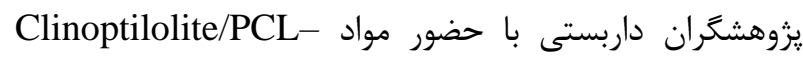
به منظور كاربرد در بافت استخوان تهيه نمودند

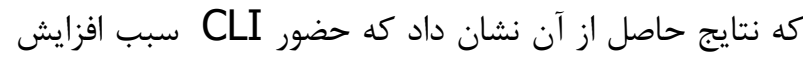
استحكام داربست، ارتقا تخلخل از هله به V9 درصد و زيست سازگارى بهتر و همينطور جذب آب كمتر را سبب كرديد. در نهايت نيز با سلول هاى human fetal osteoblasts cells آزمون برون تنى نشان داد حضور CLI سبب افزايش تكثير

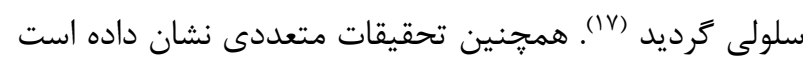

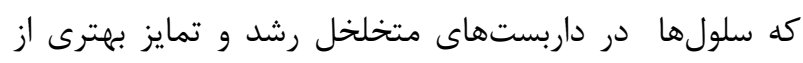

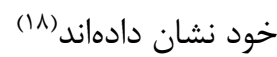
با اين وجود استفاده از داربستهاى زيست سازگار به منظور درمان نقايص استخوانى همواره با خالشهاى زيادى از جمله
تست رهايش دارو

نتايج آزمون رهايش دارو در شكل بَ آورده شده است. نمودار الف نمودار كاليبراسيون دارو در محيط رهايش، و نمودار ب رهايش دارو در طى ينج روز اول را نشان مىدهد. با توجه به شكل با افزايش غلظت داروى باركذارى شده در داربست، بازه داري

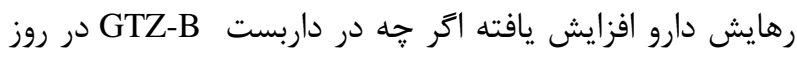
اول يك رهايش انفجارى در حدود V•/• گرم دارو مشاهده شده است كه با توجه به مقدار MIC ذكر شده در بالا، مقدار رهايش از اين مقدار بيشتر بوده است. در ادامه يك رهايش ييوستهاى از دارو به مقدار ها •/• گرم در طول بازه ينج روزه كه دوره اول التهاب استخوان است، را شاهد بودهايم.
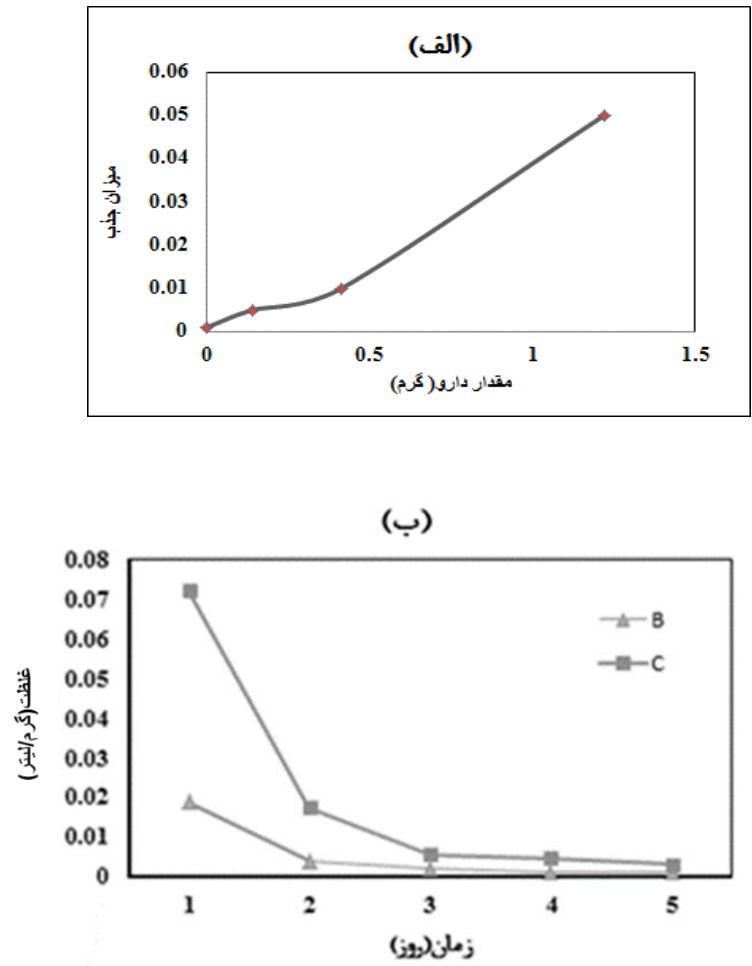

شكل r - نمودار الف: كاليبراسيون دارو كيليندامايسين با غلظتهاى

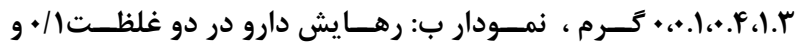

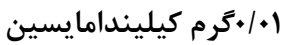
در سالهاى اخير مطالعات زيادى بر روى استفاده

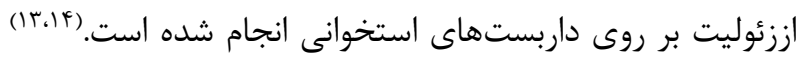
Saheban 
داربست براى جلوكيرى از التهاب و عفونت در روزهاى اول ترميم است، به نوعى مثمر ثمر واقع شده است؛ جرا كه در روز اول سيل عظيمى از ماكروفازها به محل بافت هدف روانه مىشوند و اين رهايش بالاى دارو مىتواند كمك شايانى به كاهش التهاب كند. علت اين نوع رهايش راميتوان داروى قرار كرفته روى سطح داربست و رهايش آن به محض قرار كيرى و نفوذ آب به داخل داربست دانست. نسبت رهايش دو داربست

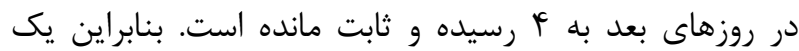
رهايش ويوسته و آهسته را از داربست شاهد بودهايم.

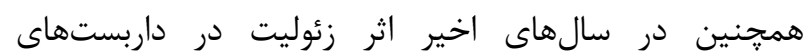
استخوانى و سيستم رهايش دارو در داربستهاى استخوانى

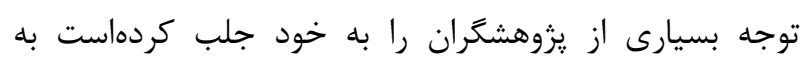

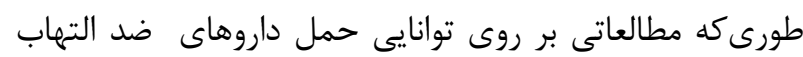
بر روى زئوليت طبيعى اصلاح شده با داروهايى نظير ibuprofen diclofenac diethylamide

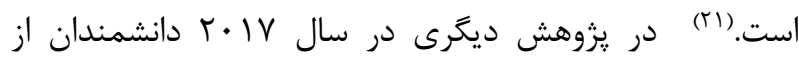
زئوليت طبيعى به عنوان ماتريسى جهت رهايش داروى Bexarotene كردند. در اين يزوهش زئوليت طبيعى به عنوان ميزبان و با

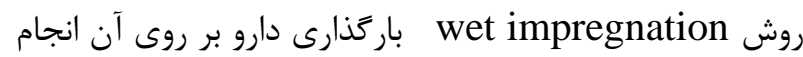
شد.(r) با توجه به : بزوهشهاى كذشته، زئوليت يكى از

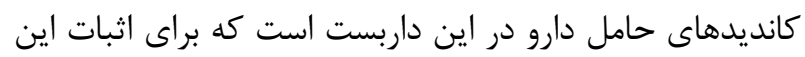

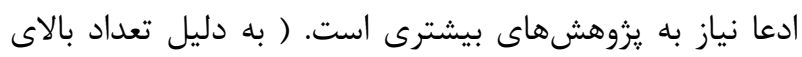

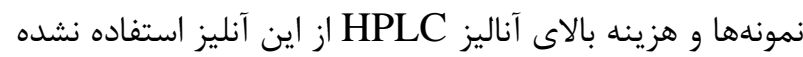

\section{نتيجه}

افزودن عامل ضد باكتريايى كليندامايسين به داربست استخوانى

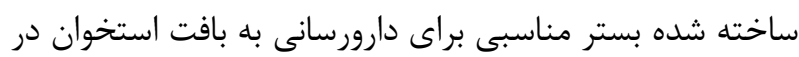

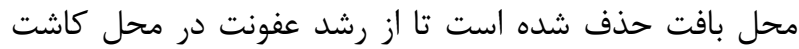
داربست در دوره اول ترميم جلوكيرى كند.
عدم استحكام، زيست سازگارى ڤِيين، طول عمر پايين سلولهاى روى داربست بوده است. در ترميم بافت استخوان

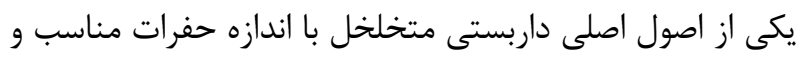

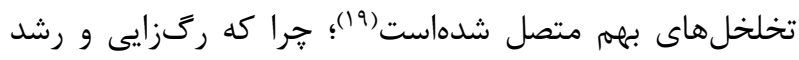
سلولها نيازمند اكسيزن و موادغذايى است. نسبت سطح به حجم بالاى داربست و همجنين ارتباط بين منافذ داربست موجب راحتى در انتقال و مهاجرت سلولها در طول داربست شده كه در نتيجه منجر به رشد سريع بافت استخوان بر روى داربست مىشود. بنابراين سايز حفرات براى ورود سلولها به داربست بايد مناسب باشد كه در بسيارى از يزوهشها اندازه حفرات بين ·ץ تا · · ميكرومتر را مناسبترين اندازه حفرات

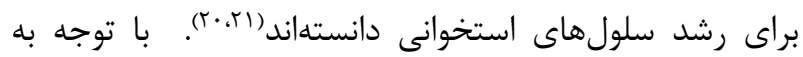
مقياس شكل 1، ساختارمتخلخل داربست ساخته شده داراى

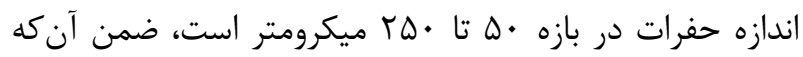
ارتباط بين خلل و فرج مشاهده مىشود. از طرفى با توجه به تصاوير، افزودن دارو با غلظتهاى مختلف بر روى داربست، تاثيرى بر ساختار فيزيكى داربست و اندازه حفرات آن نداشته

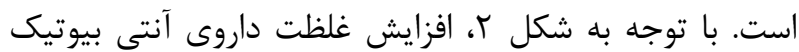

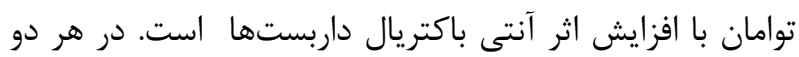

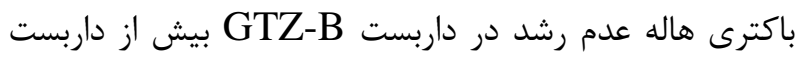

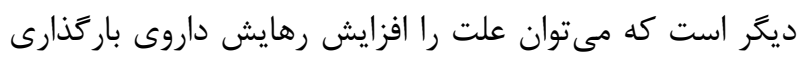

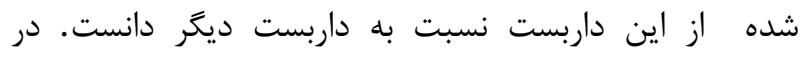
داربست GTZ-C هم به علت كمترين ميزان داروى موجود

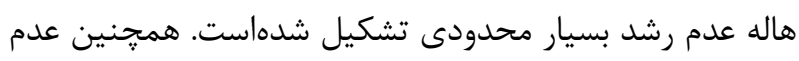
رشد هاله در اطراف داربست GTZ-A نشاندهنده عدم خاصيت آنتىباكتريايى داربست ساخته شده است؛ كه در

بسيارى از يزوهشهاى ديخر نيز به اين نكته توجه كردهاند(·) در شكل r نمودار رهايش دارو از داربستهاى ساخته شده

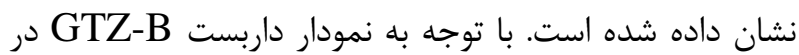

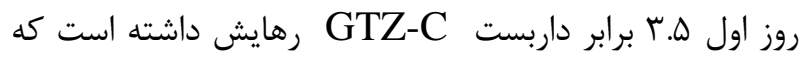

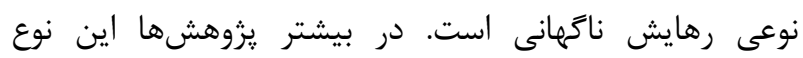

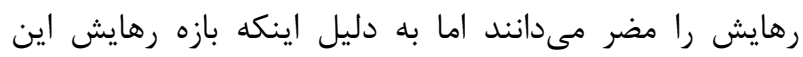


خاصيت آنتى باكتريال داربست هاى متخلخل براى درمان ضايعه استخوانى

\section{References:}

1-N. Ninan, M. Muthiah, N.A.B. Yahaya, I.-K. Park, A. Elain, T.W. Wong, S. Thomas, Y. Grohens, Antibacterial and wound healing analysis of gelatin/zeolite scaffolds, Colloids and Surfaces B: Biointerfaces 115 (2014) 244-252.

2-L. Li, Y. Li, J. Li, L. Yao, A.F. Mak, F. Ko, L. Qin, Antibacterial properties of nanosilver PLLA fibrous membranes, Journal of Nanomaterials 2009 (2009) 9. 3-G.Y. Liu, A. Essex, J.T. Buchanan, V. Datta, H.M. Hoffman, J.F. Bastian, J. Fierer, V. Nizet, Staphylococcus aureus golden pigment impairs neutrophil killing and promotes virulence through its antioxidant activity, Journal of Experimental Medicine 202(2) (2005) 209-215.

4-Y. Shebis, D. Iluz, Y. Kinel-Tahan, Z. Dubinsky, Y. Yehoshua, Natural Antioxidants: Function and Sources, Food and Nutrition Sciences 04(06) (2013) 643-649.

5-E.H. Abdulkareem, K. Memarzadeh, R. Allaker, J. Huang, J. Pratten, D. Spratt, Anti-biofilm activity of zinc oxide and hydroxyapatite nanoparticles as dental implant coating materials, Journal of dentistry 43(12) (2015) 1462-1469.

6-M. Balouiri, M. Sadiki, S.K. Ibnsouda, Methods for in vitro evaluating antimicrobial activity: A review, J Pharm Anal 6(2) (2016) 71-79.

7-H.R. Ramay, M. Zhang, Biphasic calcium phosphate nanocomposite porous scaffolds for loadbearing bone tissue engineering, Biomaterials 25(21) (2004) 5171-80.

8- J. Sundaram, T.D. Durance, R. Wang, Porous scaffold of gelatin-starch with nanohydroxyapatite composite processed via novel microwave vacuum drying, Acta biomaterialia 4(4) (2008) 932-942.

9-N. Ninan, Y. Grohens, A. Elain, N. Kalarikkal, S. Thomas, Synthesis and characterisation of gelatin/zeolite porous scaffold, European Polymer Journal 49(9) (2013) 2433-45.

10- L. Bi, Y. Hu, H. Fan, G. Meng, J. Liu, D. Li, R. Lv, Treatment of contaminated bone defects with clindamycin-reconstituted bone xenograft-composites, Journal of Biomedical Materials Research Part B: Applied Biomaterials: An Official Journal of The Society for Biomaterials, The Japanese Society for Biomaterials, and The Australian Society for Biomaterials and the Korean Society for Biomaterials 82(2) (2007) 418-427.

11-D. Algul, A. Gokce, A. Onal, E. Servet, A.I. Dogan Ekici, F.G. Yener, In vitro release and In vivo biocompatibility studies of biomimetic multilayered alginate-chitosan/beta-TCP scaffold for osteochondral tissue, J Biomater Sci Polym Ed 27(5) (2016) 431-40. 12-M. Saheban, H.R. Bakhsheshi-Rad, M. KasiriAsgarani, E. Hamzah, A.F. Ismail, M. Aziz, E. Dayaghi, Effect of zeolite on the corrosion behavior, biocompatibility and antibacterial activity of porous magnesium/zeolite composite scaffolds, Materials Technologv 34(5) (2019) 258-269.
13-A. Sadeghinia, S. Soltani, M. Aghazadeh, J. Khalilifard, S. Davaran, Design and fabrication of clinoptilolite-nanohydroxyapatite/chitosan-gelatin composite scaffold and evaluation of its effects on bone tissue engineering, Journal of Biomedical Materials Research Part A 108(2) (2020) 221-33.

14-E. Pazarçeviren, Ö. Erdemli, D. Keskin, A. Tezcaner, Clinoptilolite/PCL-PEG-PCL composite scaffolds for bone tissue engineering applications, Journal of biomaterials applications 31(8) (2017) $1148-1168$

15- A. Uyumaz, L. Ozyegin, N. Buyukakyuz, B. Yesilbek, F.N. Oktar, Evaluation of TCP loaded clinoptilolite use as graft material on rabbit tibia, Key Engineering Materials, Trans Tech Publ, 2012, pp. $175-180$

16- K. Dahlan, N.A. Nuzulia, S.T. Wahyudi, S. Utami, Effects of $\mathrm{Na}$ Alginate in the Porosity of Scaffold Biphasic Calcium Phosphate/Alginate Composites, Key Engineering Materials 696 (2016) 183-186.

17-M. Azami, S. Tavakol, A. Samadikuchaksaraei, M.S. Hashjin, N. Baheiraei, M. Kamali, M.R. Nourani, A porous hydroxyapatite/gelatin nanocomposite scaffold for bone tissue repair: in vitro and in vivo evaluation, Journal of Biomaterials Science, Polymer Edition 23(18) (2012) 2353-2368.

18-B.P. Kumar, V. Venkatesh, K.A.J. Kumar, B.Y. Yadav, S.R. Mohan, Mandibular Reconstruction: Overview, Journal of Maxillofacial and Oral Surgery 15(4) (2016) 425-441.

19-G. Odin, C. Savoldelli, P.-O. Bouchard, Y. Tillier, Determination of Young's modulus of mandibular bone using inverse analysis, Medical engineering \& physics 32(6) (2010) 630-637.

20- Y. Lan, W. Li, Y. Jiao, R. Guo, Y. Zhang, W. Xue, Y. Zhang, Therapeutic efficacy of antibioticloaded gelatin microsphere/silk fibroin scaffolds in infected full-thickness burns, Acta biomaterialia 10(7) (2014) 3167-3176.

21- L. Ochiuz, C. Ghiciuc, M. Ignat, M. Popa, C.A. Peptu, A. Vasile, Development of a modified-release drug delivery system with bexarotene loaded in clinoptilolite, Mater. Plast 54 (2017) 581-585. 